\title{
PHILOSOPHY OF METAPHOR AND BLUMENBERG'S METAPHOROLOGY
}

\author{
Ovcharenko N. M. \\ аспірант кафедри теорії культури \\ і філософії науки філософського факультету \\ ХНУ імені В. Н. Каразіна, ovcnataliia@gmail.com \\ Post-graduate student of the department \\ of cultural studies and philosophy of science, \\ Kharkiv Karazin University \\ ORCID 0000-0002-1243-8982
}

In the article metaphorology is considered in the light of paradigms. Metaphors of 'mighty' and 'naked' truth are analysed as well as two backgrounds of metaphorics. Absolute metaphor in Blumenberg's understanding is researched. It is concluded that absolute metaphor differs from 'ordinary' metaphors and confronts terminology. Hans Blumenberg in his book "Paradigms for a Metaphorology" makes a suggestion that elements of figurative speech are makeshifts to be replaced by logic. He claims that history of concepts can be only destructive: it is demolishing burden of tradition (corresponds to Francis Bacon 's 'idols').

When analysing the metaphor of 'mighty' truth, H. Blumenberg links it to the closest metaphor of light, then to metaphorics of imprinting. Here he accepts that metaphors in this function do not obligatory appear in the lexical sphere of expression. Later on he raises the question of the truth of metaphor itself. Blumenberg's metaphorics of the 'naked' truth is rather catching. Metaphor goes side by side with importance of 'clothing', some mask, while the 'naked truth' should unveil the 'sacred mystery'.

First of all, Blumenberg indicates two kinds of metaphors: absolute metaphors (basic language elements) and 'leftover elements'. It should be underlined that absolute metaphors cannot be dissolved into conceptuality and one of such metaphors cannot be replaced by any other. If we try to compare metaphor and allegory, allegory is more connected with dogmatism. As for metaphor and symbol, the latter is static while metaphor is more dynamic. Also two backgrounds of metaphorics: organic and mechanical - are profoundly analysed by Blumenberg. And finally, unlike absolute metaphor myth has unclear origin.

Keywords: metaphorology, absolute metaphor, concept, paradigm, organic and mechanical metaphors.

\section{ОВчаренКо Н. М. ФІЛОСОФІЯ МЕТАФОРИ ТА МЕТАФОРОЛОГІЯ БЛЮМЕНБЕРГА}

У статті метафорологія розглядається в світлі парадигм. Аналізуються метафори "значної" та "оголеної" правди, а також два фони метафорики. Досліджується абсолютна метафора у розумінні Блюменберга. Зроблено висновок про те, що абсолютна метафора відрізняється від "звичайних" метафор та протиставляється термінології.

Ганс Блюменберг у своїй книзі "Парадигми метафорології" висловлює думку про те, що елементи образної мови - це модифікації, які повинні бути замінені логікою. Він стверджує, що історія понять може бути лише руйнівною: це руйнує тягар традиції (відповідає "ідолам" Френсіса Бекона).

Аналізуючи метафору "значної" правди, Г. Блюменберг пов'язує ї̈ з найближчою метафорою світла, потім з метафорикою відбитка. Тут він приймає те, що метафори у цій функції не обов'язково знаходять своє вираження у лексичній сфері. Пізніше він ставить питання про правду самої метафори. Метафорика "оголеної" правди Блюменберга досить приваблива: метафора йде поруч з важливістю "одягу", деякої маски, тоді як "гола правда" повинна розкрити "священну таємницю".

Перш за все, Блюменберг вказує на два види метафор: абсолютні метафори (основні елементи мови) та "залишкові елементи". Слід підкреслити, що абсолютні метафори не можуть бути "розчинені" 
у концептуальності, і одна з таких метафор не може бути замінена якоюсь іншою. Якщо ми намагаємось порівняти метафору та алегорію, то алегорія більше пов'язана з догматизмом. Що стосується метафори та символу, то останній статичний, тоді як метафора $є$ більш динамічною. Також два фони метафорики: органічний та механічний - глибоко проаналізовані Блюменбергом. I нарешті, на відміну від абсолютної метафори, міф має невизначене походження.

Ключові слова: метафорологія, абсолютна метафора, концепт, парадигма, органічні та механічні метафори.

\section{ОвчаренКО Н. Н. ФИЛОСОФИЯ МЕТАФОРЫ И МЕТАФОРОЛОГИЯ БЛЮМЕНБЕРГА}

В статье метафорология рассматривается в свете парадигм. Анализируются метафоры «значительной» и «оголённой» правды, а также два фона метафорики. Исследуется абсолютная метафора в понимании Блюменберга. Сделан вывод, что абсолютная метафора отличается от «обычных» метафор и противоставляется терминологии.

Ханс Блюменберг в своей книге «Парадигмы для метафорологии» высказывает предположение, что элементы образной речи - это модификации, которые должны быть заменены логикой. Он утверждает, что история понятий может быть только разрушительной: она разрушает бремя традиции (соответствует «идолам» Фрэнсиса Бэкона).

Анализируя метафору «значительной» истины, Х. Блюменберг связывает её с ближайшей метафорой света, а затем с метафорикой отпечатка. Здесь он допускает, что метафоры в этой функции не обязательно находят своё выражение в лексической сфере. Позже он поднимает вопрос о правде самой метафоры. Метафорика Блюменберга о «голой» правде довольно привлекательна: метафора идёт рядом с важностью «одежды», некоторой маски, в то время как «голая правда» должна раскрыть «священную тайну».

Прежде всего, Блюменберг указывает два вида метафор: абсолютные метафоры (основный элементы языка) и «остаточные элементы». Следует подчеркнуть, что абсолютные метафоры не могут быть «растворены» в концептуальности, и одна из таких метафор не может быть заменена какой-либо другой. Если мы пытаемся сравнить метафору и аллегорию, то аллегория больше связана с догматизмом. Что касается метафоры и символа, последний статичен, тогда как метафора более динамична. Также Блюменберг глубоко анализирует два фона метафорики: органический и механический. И, наконец, в отличие от абсолютной метафоры, миф имеет неясное происхождение.

Ключевые слова: метафорология, абсолютная метафора, концепт, парадигма, органические и механические метафоры.

Hans Blumenberg is well-known as the author of the term 'metaphorology' which analyses things meant by metaphors. Metaphorology is rather relevant nowadays because in consumer society it is necessary to convince the customer to buy certain products and as metaphor has great emotional influence on human beings and thus can be used in any marketing strategies it is being studied profoundly.

Metaphor attracted attention of many scientists beginning from Aristotle, Cicero and ending with Cassirer, Ortega y Gasset, Peirce and many others. Our article is aimed at investigating metaphors using Blumenberg's approach, figuring out kinds of metaphors and analysing metaphorical paradigms. We use historical, hypothetic and deductive methods in our research. The object of the article is metaphorology, the subject is metaphor in paradigms.

Hans Blumenberg in his book "Paradigms for a Metaphorology" makes a suggestion that elements of figurative speech are makeshifts to be replaced by logic. He claims that history of concepts can be only destructive: it is demolishing burden of tradition (corresponds to Francis Bacon's 'idols'). Metaphor is considered 'transferred speech': a poet cannot say something which can be transferred to concepts or theory and in his speech it matters how he talks more than what he says (persuasive speech).

Metaphors can be of two kinds. First of all, they can be leftover elements or "rudiments on the path from mythos to logos" [1, p. 3]. Secondly, they may be foundational elements of philosophical language and cannot be converted back into logicality ('translations', absolute metaphors). Absolute metaphors make us reconsider relationship between logos and imagination. It should be noted that imagination according to the author is the sphere where logos finds the source of its concepts and where concepts renew.

Before analysing the relationship between metaphor and concept it is reasonable to turn to the meaning of the term 'concept'. Concept is the content of certain notion or sense meaning of notion or sign. Applying to Kant's "transportation of reflection" in "Critique of the Power of Judgment" $\mathrm{H}$. Blumenberg presents absolute metaphor as "the transportation of the reflection on one object of intuition to another, quite different concept, to which perhaps no intuition can ever directly correspond" 
$[1$, p. 4]. The fact that these metaphors were called 'absolute' for author means that they confront terminology and will not be dissolved into conceptuality. Moreover, in case of such metaphors one metaphor cannot be replaced by another, more precise one. Therefore absolute metaphors have a history which differs gradually from a history of concepts, that is, transformation of metaphor reveals the historical horizons of meaning and the substructure of thought.

When analysing the metaphor of 'mighty' truth, H. Blumenberg links it to the closest metaphor of light, then to metaphorics of imprinting. Here he accepts that metaphors in this function do not obligatory appear in the lexical sphere of expression. Later on he raises the question of the truth of metaphor itself: "metaphors are unable to satisfy the requirement that truth, by definition, be the result of a methodologically secure procedure of verification" [1, pp. 13-14] because they do not tell any truthful facts. Metaphor should be acknowledged as a historical object with their historical truth: they give structure to a world, represent reality which hasn 't been experienced yet. H. Blumenberg considers the Absolute to be encountered in one's aesthetic experience.

As for allegory, it may be heterogeneous to metaphor but not as a thought born in the image but it can be used in the function of metaphor. Gadamer H. G. in "Symbol und Allegorie" [2, p. 27] claims that the concept of allegory is connected with dogmatism beginning from the rationalization of mythical. At this moment art freed itself from dogmatism and as a result allegory became "aesthetically suspect" [2, p. 79]. Thus allegory was finished. We consider that thought isn't born in image but can exist even in the form of feelings when the thought is not born yet. Our suggestion is that the fact that human being can have dreams of the symbolic nature proves that thought was originally born in symbols and image is a visualized symbol. Metaphor can't present the truth fully but truth can't be presented fully also in the language. Truth can be mostly presented via body language, humour, or art rather than via language because it represents the own truth of any peoples. In our opinion any stage of evolution of human society is followed by changes in the way of transferring the meaning by figurative language: for example mythical way of 'thinking' in ancient times, influence of allegory in medieval times or shift to terminology with the 'birth' of science.

The concepts of truth and knowledge should be considered carefully when analysing metaphor because they can be viewed as a basis of metaphor. Descartes characterizes knowledge as overcoming of obstacles as he himself found truth in the sciences and found five or six difficulties when obtaining knowledge which he managed to overcome. As for truth, it is mentioned that it cannot be shown, the truth is "dark" and sometimes we need to reveal the "lost" truth. Neither truth nor beauty is presented "unhidden" to mankind. Montesquieu claims that we accept the truth at the strongest point and search it "in the darkness", besides, nowadays it is not truth which causes discoveries but new methods for finding the truth. Goethe notices that phenomena should be freed from elements of empiricism, mechanism and dogmatism; that is, common sense should "decide" if the phenomenon is truthful or not. Moreover, theories are often just rushed conclusions and include images, concepts or words.

In ancient and medieval times truth couldn't be obtained because it was considered that only God could possess the truth. Democritus`s metaphorical acception of truth as hidden in the well for Blumenberg is a false metaphor because, vice versa, truth is high in heaven, that is, it cannot be achieved. Lactantius determines the most important function of metaphorics: he views it as relationship between truth and rhetoric. "Metaphor outlives [...] vital function of expressing one of the ontological surmises underlying and governing all conduct, figuring henceforth only as a kind of pragmatic crutch", [1, p. 39] claims Blumenberg.

Blumenberg's metaphorics of the 'naked' truth is rather catching. Metaphor goes side by side with importance of 'clothing', some mask, while the 'naked truth' should unveil the 'sacred mystery'. Even the fact that human being covers his body with clothes speaks for the fact that truth should be 'covered', says the author. Franz Werfel in "Theologumena" describes naked truth as the 'whoring bride' of the barbarian. Blumenberg adds that any culture begins the moment when something is hidden. We can set our own examples from the point of view of the Slavonic person: in European cultures the individuality seems to be hidden because society sets up the only possible models of behaviour; in Eastern (Asian and Arabian) cultures body is 'hidden', it is shameful to show your body (both for men and women), carnal relationship of people of opposite sex should be hidden from the eye of society (kissing and touching in public is forbidden even for husband and wife). In Slavonic cultures maybe some potential to deeds is hidden which can be revealed suddenly. 
In the understanding of truth Pascal pays special attention to the concept of imagination: "Reason never entirely overcomes the imagination, whereas the imagination often completely drives reason from its throne" [4, p. 19]; "Imagination orders everything. It is the spring of beauty, justice, and happiness which is the be-all and end-all of the world" [4, p. 19]. Actually Pascal mentions that people have no definite principle of truth. In times of Enlightenment the discovery was made that the truth wasn't actually 'naked': the 'masks' of truth are not taken from the poetry but now form the way in which truth can be expressed. Breitinger pays attention to so-called metaphorical 'sugar coating': truth should be 'sweatened' by it. To add, metaphors mark the territory where terminology supplies details and the creation process will never stop.

H. Blumenberg thinks there are two backgrounds of metaphorics: organic and mechanical. Firstly, metaphorics can exist where terminological propositions exist with the 'guiding idea'. He suggests to call some translations 'background metaphorics', it is "only within the parameters of a certain typology, and this is more likely to occur where a prior decision between opposed kinds of metaphors between organic and mechanical guiding ideas, for example - has been made" [1, p. 63]. Geoffrey Gorer notes that European metaphors are organic while American metaphors are mechanical [3, p. 116]. As examples of mechanical metaphors 'machina mundi' (one of its meanings is 'a tool') and 'clockwork metaphor' are suggested. Such metaphors as 'machine' nowadays contest the 'organic' metaphor. In his "Principia" Descartes explains the structure of knowledge when saying that he described the earth and the universe as if they were a machine. Thus, the difference between organic and mechanical metaphors is just quantitative. Actually, the clock metaphor represents man as one of the components of the machine. According to Blumenberg, spiritual and mechanical metaphors do not explain the world as reality but as science. And, in our opinion it was science that influenced the role of metaphor and changed the principles of its work.

Considering metaphorology as a subbranch of conceptual history, he then pulls the reader's attention to the transition in the relationship of metaphorics and myth. First of all, it is well-known that mythos is considered to be a 'preliminary form' of logos and a primitive form of mental 'growth'. In this regard, it is important to specify the difference between myth and 'absolute metaphor' as a genetic one: if myth has unclear origin, metaphor can be presented clearly as an outcome of imagination. Thus, myth is considered as a model used to explain a cosmogonic 'hypothesis'.

Apparently, the processes of terminologization of metaphor should be analysed. Transitions from metaphors to concepts can be performed in several ways: metaphor can be 'absorbed' by the word; it can be 'flattened' by terminological expression; or it can be foregrounded again in a shift in focus. Of course, metaphor has some roots in ancient rhetoric: any orator could make truth 'visible' as well as make it look 'false'. Blumenberg doesn 't consider Academicians as people who didn't know how to give the names to things correctly: probably, their terms were chosen more to conceal something from 'unintelligent' people and make it clear to an intelligent person. Firstly, the intellect can give reason to the term, secondly, will cannot 'force' intellect to assent to probable thing. Thus, the will 'orders' the intellect to give a name through faith or wisdom.

First we can get an impression that the author gives the examples and profoundly analyses the 'transition' only from metaphors to concepts and thus tries to give a typology of metaphor histories but in the chapter "Metaphorized Cosmology" he shows a type of metaphor history which goes in the opposite direction, that is from concepts to metaphors. Thus, metaphorical realism is considered as an important factor in the forming of historical life because no other paradigm can better demonstrate this than 'cosmology'.

Analysing geometric symbolism and metaphorics, Blumenberg claims that symbol captures only the identity of a relationship, it subserves the identification but it is meaningless as for its content. Nevertheless there are situations when symbolic and metaphorical functional elements come together. He set an example when, with the help of metaphor, circle and sphere are considered as forms of cosmic orbits and bodies. When mythic symbol is 'overloaded' with content, becomes very 'meaningful', it may become a metaphor. Moreover, 'the structure of metaphor itself is metaphysically hypostasized' [1, p. 122]. Another difference we can view between symbol and metaphor: while symbol 'serves' the knowledge and must be fixed and static, metaphor represents movement, sometimes rather complex. Socalled 'explosive metaphors' draw intuition to process where at first it cannot cease.

There are some issues in mathematics which author admires: firstly, it allows free manipulation and experiments under chosen conditions; secondly, in mathematics we face only finite things in spite of 
the fact that the world is infinite. Author claims that the main reason for using symbolism in studying spiritual things cannot be understood but all things here are in some kind of relation to each other. Metaphor is good for using because it "requires each of its elements to be interpreted according to its function" [1, p. 126], otherwise it changes into allegory. Thus, author concludes that "absolute metaphor leaps into a void, inscribing itself on the tabula rasa of theoretical unsatisfiability; here it has occupied the position of the defunct absolute will. Metaphysics has often revealed itself to us to be metaphorics taken at its word; the demise of metaphysics calls metaphorics back to its place" [1, p. 132]. In paradigms the place of the absolute is taken by "absolute metaphor", so the absolute is metaphorized.

As a result of our research we can make the following conclusions. First of all Blumenberg indicates two kinds of metaphors: absolute metaphors (basic language elements) and 'leftover elements'. It should be underlined that absolute metaphors cannot be dissolved into conceptuality and one of such metaphors cannot be replaced by any other. If we try to compare metaphor and allegory, allegory is more connected with dogmatism. As for metaphor and symbol, the latter is static while metaphor is more dynamic. Also two backgrounds of metaphorics: organic and mechanical - are profoundly analysed by Blumenberg. And finally, unlike absolute metaphor myth has unclear origin.

So metaphor is classified by Blumenberg into several categories and actually absolute metaphor, organic and mechanical are subjects for our further investigations in metaphorology.

\section{REFERENCES}

1. Blumenberg H. Paradigms for a Metaphorology / Hans Blumenberg. - Ithaca, New York: Cornell University Press and Cornell University Library, 2010. - $152 \mathrm{p}$.

2. Gadamer H. G. Truth and Method / Hans-Georg Gadamer. - New York: Crossroad, 1989. - 601 p.

3. Gorer G. The Americans: A Study in National Character / Geoffrey Gorer. - London: The Cresset Press, 1948.

4. Pascal B. Pensees and Other Writings / Blaise Pascal - Fragment 82, Imagination. - Oxford World`s Classic, 2008. $-320 \mathrm{p}$. 